\title{
EFEKTIFITAS PROGRAM SERVANT LEADERSHIP TERHADAP KEPUASAN KARYAWAN DI INDUSTRI FARMASI
}

\author{
Tri Bekti Agung Wibowo \\ Program Studi Magister Manajemen, Universitas Airlangga \\ Email: tribektiagung@gmail.com
}

\begin{abstract}
Abstrak: Saat ini, generasi milenial mulai menduduki persentasi tertinggi dalam angkatan kerja di berbagai industri. Dari berbagai literatur. gaya servant leadership cocok untuk diterapkan pada organisasi yang berisi generasi millennial. Dalam penelitian ini, yang menjadi subjek penelitian adalah karyawan dari para manager peserta program servant leadership training. Ada 6 manager (disebut dengen kode A, B, C, D, E dan F) yang diteliti dalam studi ini. Hasil kuesioner dianalisa menggunakan uji validity, uji reliability dan paired t-test. Hal ini untuk menguji signifikansi pengaruh program servant leadership training. Kemudian dilanjutkan menggunakan kalkulasi satisfaction index (SI) dengan weighted scoring pada 3 dimensi (listening, persuasion, foresight). Hal ini dikarenakan program training yang dilakukan berfokus pada listening, persuasion dan foresight. Hasil SI kemudian dibandingkan antara sebelum dan sesudah training. Hasil penelitian secara umum menunjukkan perbedaan antara sebelum dan sesudah program training, dengan kata lain: secara umum terdapat dampak efektifitas program training yang dijalankan terhadap kepuasan karyawan di industri farmasi.
\end{abstract}

Kata kunci: Servant Leadership, Kepuasan Karyawan, Industri Farmasi

Absract: Nowadays, the millennial generation starts to occupy the highest percentage of the workforce in various industries. From numerous literature. servant leadership style is suitable to be applied to organizations that contain millennials. In this study, the research subject is the employee of the managers participating in the servant leadership training program. There are 6 managers (called with code $A, B, C, D$, $E$, and $F$ ) that are examined in this study. The results of the questionnaire were analyzed using a validity test, reliability test and paired t-test. The purpose is to test the significant influence of the servant leadership training program. Then proceed calculation using satisfaction index (SI) with weighted scoring in 3 dimensions (listening, persuasion, foresight). This is due to the training program conducted focuses on listening, persuasion and foresight. SI results then compared between before and after the training program. The results of the study generally indicate the difference between before and after the training program, in other words: there is an effective impact of the training program on employee satisfaction in the pharmaceutical industry.

Keywords: Servant Leadership, Employee Satisfaction, Pharmaceutical Industry

Article History: Received 2020-03-07; Revised 2020-04-08; Accepted 2020-04-13

\section{PENDAHULUAN}

Saat ini, istilah generasi millennial sedang banyak dibahas di berbagai topik pembicaraan. Awalnya, istilah tersebut berasal dari kata "millennials" yang diciptakan oleh William Strauss dan Neil Howe dalam beberapa bukunya. Millennial generation atau generasi Y juga akrab disebut generation me atau echo boomers. Secara harfiah memang tidak ada demografi khusus dalam menentukan kelompok generasi yang satu ini. Namun, para pakar menggolongkannya berdasarkan tahun awal dan akhir. Penggolongan generasi Y terbentuk bagi mereka yang lahir pada 1980 - 1990, atau pada awal 2000, dan seterusnya (Azizah \& Livikacansera, 2016). Millennial, pada umumnya merupakan anak dari generasi baby boomer. Dimana generasi baby boomer membesarkan anak- 
anak mereka dengan harapan besar dan memberikan anak-anak mereka sumber daya yang lebih melimpah dibandingan apa yang sudah mereka dapatkan saat anak-anak (Gong et al, 2019). Menurut paper yang dipublikasikan oleh White House, millennial memiliki tingkat pendidikan yang baik, cerdas teknologi, dan menghargai keluarga serta komunitas. Di Indonesia studi dan kajian tentang generasi millennial belum banyak dilakukan, padahal secara jumlah populasi penduduk Indonesia yang berusia antara 15-34 tahun saat ini sangat besar, 34,45\% (Corinna \& Cahyono, 2019)

Mengacu pada artikel dari Nawalkha (2018), generasi millennial merasa bahwa kerja tidak hanya sekedar mendapatkan gaji. Mereka menginginkan pekerjaan yang memiliki tujuan jelas. Generasi sebelumnya bisa saja sekedar menyelesaikan pekerjaan dan mendapatkan gaji darinya. Namun generasi millennial menginginkan menyelesaikan pekerjaan dengan benar dan mendapatkan gaji setelah itu. Jelas terlihat bahwa generasi millennial menginginkan pekerjaan yang berbeda daripada pekerjaan sebelumnya.

Pada saat ini di kebanyakan perusahaan, dan juga yang terjadi di perusahaan yang menjadi objek penelitian, sedang mengalami tahap asimilasi, dimana para pemegang keputusan cenderung berasal dari generasi sebelumnya (baby boomer atau generasi X), sedangkan kebanyakan karyawan entry level merupakan generasi millennial. Perbedaan karakter tersebut seringkali menjadi tantangan tersendiri dalam kerjasama tim dan komunikasi harian.

Studi ini mengambil objek penelitian pada salah satu perusahaan farmasi di Indonesia. Menurut Leslie \& Palmisano (2014), perusahaan farmasi menghadapi isu kompleks yang semakin menantang tiap harinya. Reformasi pelayanan kesehatan dan perubahan di teknologi, kebijakan pemerintah dan harapan konsumen mengubah hubungan antara pemangku kepentingan dengan kegiatan operasional terdampak dengan cara yang tidak terduga. Sebagian besar ahli percaya bahwa perusahaan akan sukses dalam menghadapi tantangan tersebut bila menempatkan penekanan baru pada inovasi. Lebih lanjut, perusahaan akan beradaptasi secara efektif dalam menghadapi perubahan dan ketidak pastian, dan akan memposisikan diri mereka sebagai mitra yang penting dalam rantai pasokan pelayanan kesehatan.

Berdasarkan data olahan internal perusahaan pada tahun 2019, jumlah karyawan millennial (dengan usia kurang dari 30 tahun) mencapai 43\% (128 dari 295 total karyawan). 105 dari karyawan tersebut berada pada staff level ke atas, dengan rata-rata masa kerja kurang dari 5 tahun.

Dari berbagai literatur, gaya servant leadership cocok untuk diterapkan pada organisasi yang berisikan generasi millennial. Servant leadership, secara empiris dapat membantu dalam peningkatan kinerja pekerjaan, komitmen organisasi, perilaku dalam organisasi, dan engagement (Bao et al, 2018). Menurut Melchar \& Bosco (2010), servant leader dapat sukses dalam organisasi jasa yang kompetitif dan mengejar profit. Teori kepemimpinan ini perlu diteliti secara empiris di lingkungan bisnis lainnya untuk mengetahui adanya faktor internal dan eksternal yang dapat mempengaruhi efektifitasnya. Kajian mengenai praktek servant leader di organisasi lainnya dapat meningkatkan pemahaman mengenai perilaku servant leader dan pengaruhnya dalam mempromosikan budaya kerja yang positif dan meningkatkan kinerja organisasi. Sakeru et al (2019) menyatakan banyak kalangan berpendapat bahwa employee engagement harus menjadi perhatian serius oleh pihak eksekutif puncak agar perusahaannya dapat bertahan dari fenomena turnover yang tinggi. Employee engagement merupakan salah satu cara untuk membuat karyawan memiliki loyalitas yang tinggi

Berdasarkan penelitian yang dilakukan oleh Charles (2015), servant leadership memberikan efek positif pada kepuasan karyawan terhadap pemimpinnya. Menurut McCann et al (2014) terdapat korelasi yang kuat antara servant leadership dan kepuasan karyawan. Menurut Farrington \& Lillah (2018), servant leadership memberikan pengaruh positif terhadap kepuasan kerja dan

Tri Bekti Agung Wibowo- Efektifitas Program Servant Leadership Terhadap Kepuasan Karyawan Di Industri Farmasi [Vol 11, No 1 (2020): April 2020] JBTI 
memainkan peranan penting dalam memberikan kualitas pelayanan yang lebih baik di sektor pelayanan kesehatan.

Perusahaan bergerak cepat untuk meningkatkan kepuasan kerja karyawan melalui program servant leadership yang dimulai dari 2018, dengan melibatkan para manager inti sebagai peserta program. Namun belum ada studi yang dilakukan perusahaan untuk membuktikan efektifitas program training tersebut dalam meningkatkan kepuasan kerja terhadap karyawan di industri farmasi. Penelitian ini penting dilakukan dalam upaya mempertahankan kinerja organisasi melalui program servant leadership di tengah kondisi dominasi generasi millennial dalam perusahaan. Selain itu penelitian ini juga bertujuan untuk menganalisa efektifitas program servant leadership dalam membangun kepuasan kerja karyawan dalam organisasi saat ini.

\section{KAJIAN TEORI}

\section{Servant Leadership}

Berdasarkan studi yang dilakukan Liden et al (2014), servant leadership berlandaskan pada pemahaman bahwa pemimpin harus mempunyai kemampuan untuk memotivasi bawahannya, dan lebih memprioritaskan pemenuhan kebutuhan bawahannya daripadanya dirinya sendiri. Hal ini akan mendorong hubungan yang kuat dengan bawahannya dan menciptakan rasa saling keterikatan dalam pekerjaan. Servant leadership terdiri dari beberapa dimensi, termasuk diantaranya emotional healing, menciptakan nilai pada komunitas, conceptual skill, membantu pengembangan karyawan, memprioritaskan kebutuhan bawahan, dan bersikap secara etis.

Berdasarkan penelitian dari Long (2017) mengenai pengaruh gaya kepemimpinan transformasional, ethical dan servant leadership terhadap motivasi generasi millennial, disimpulkan bahwa ketiga gaya kepemimpinan tersebut efektif dalam memotivasi karyawan millennial. Namun dari hasil studi ditemukan bahwa gaya servant leadership yang memillki hubungan paling kuat dalam memotivasi karyawan millennial.

Menurut Barbuto Jr \& Gottfredson (2016), tipe kepemimpinan servant leader secara unik cocok dalam memenuhi harapan dari generasi millennial, karena berfokus pada kebutuhan dan pengembangan bawahannya. Kabar baiknya, servant leadership dapat ditrainingkan. Pelatihan servant leadership mungkin memerlukan perubahan dalam organisasi untuk menjadi lebih fokus pada karyawan, perubahan ini diperlukan apabila organisasi ingin menarik dan menahan talenta dari generasi millennial. Organisasi dipercaya memiliki kemampuan dalam menarik dan menahan talenta utamanya dengan mempromosikan dan mentrainingkan pemimpin mereka untuk menjadi servant leader. Servant leader secara unik terkualifikasi untuk menarik dan menahan para millennial, karena apa yang dicari oleh para millennial sesuai dengan apa yang dapat diberikan oleh servant leader.

Hasil studi Arain et al (2019) menyatakan bahwa terlepas dari keterbatasan dalam mengimplementasikan servant leadership, konsep ini memiliki implikasi penting untuk dipraktekkan. Adanya servant leadership dapat membantu para karyawan agar lebih aktif dalam memberikan pendapatnya dan memberikan rasa keterikatan karyawan untuk terlibat dalam aktifitas organisasi walaupun beresiko. Konsep servant leadership juga dapat diaplikasikan saat rekrutmen dan promosi karyawan. Selain itu, penggunaan servant leadership oleh manajemen puncak dapat memberikan pesan positif ke para manager dan karyawannya mengenai pentingnya strategi servant leadership dalam organisasi.

Berdasarkan hasil studi Eva et al (2019), servant leadership telah menunjukkan peningkatan tingkat efektivitas pada tim, keamanan psikologis tim, dan kreativitas serta tingkat inovasi tim. Di tingkat organisasi, servant leadership telah ditemukan berhubungan positif dengan kinerja perusahaan.

Servant leadership, sesuai yang dijelaskan oleh Brewer (2010), memiliki beberapa karakter/dimensi penting: 


\section{a. Listening}

Kemampuan mendengarkan orang lain merupakan pondasi untuk membangun hubungan dengan bawahan. Dengan mendengarkan, kita akan mendapatkan pengetahuan. Mendengarkan merupakan hal yang luar biasa, hal tersebut membuat pemimpin mendapatkan informasi dan menemukan makna terhadap apa yang disampaikan kepadanya.

b. Empathy

Empathy dimulai dengan memahami bahwa pemimpin bertanggungjawab untuk mengatur kelompok yang terdiri dari berbagai individu. Servant leader, secara personal, mengetahui masing-masing bawahannya, dan memberikan apresiasi ke setiap orang yang sudah bekerja.

c. Healing

Pemimpin harus menyadari bahwa hati manusia sangat rentan. Pemimpin harus memahami secara cepat setiap individu yang sedang membutuhkan pertolongan, dan mendampinginya saat proses penyembuhan. Seringkali menyakiti orang, akan berdampak dengan menyakiti orang yang lainnya lagi, dan hal ini akan mempengaruhi tujuan yang akan dicapai organisasi.

d. Awareness

Menjadi sadar terhadap situasi organisasi, terutama dalam hal moral dan etika, akan menjadikan pemimpin menjadi lebih baik dalam menangani konflik yang ada.

e. Persuasion

Pemimpin yang otoriter membuat keputusan berdasarkan posisi dan jabatan daripada persuasi. Servant leader membangun kesepakatan yang efektif terhadap kelompoknya dengan tujuan untuk membawa perubahan. Kemampuan meyakinkan orang lain merupakan pondasi dari kerjasama tim.

f. Foresight

Merupakan kemampuan yang dipelajari dari kesalahan masa lalu, dan muncul dari sebuah kegagalan. Foresight mencegah untuk mengulangi kesalahan yang sama.

\section{g. Stewardship}

Merupakan kesadaran diri untuk ikut bertanggungjawab terhadap kesuksesan maupun kegagalan organisasi. Stewardship seperti melayani orang lain, komitmen untuk memenuhi kebutuhan orang lain.

h. Komitmen untuk pengembangan karyawan

Servant leader memahami dinamisasi dalam pembagian tanggungjawab dan delegasi. Pemimpin memahami kelebihan dan kelemahan karyawannya, dan memberikan tugas sesuai kelebihan masing-masing karyawannya. Servant leader berkontribusi dalam memberikan sumber daya yang dibutuhkan untuk pengembangan karir karyawannya.

i. $\quad$ Building community

Komunitas merupakan cerminan dari karyawan sebuah organisasi, dan servant leader diharapkan dapat menjangkau diluar batasan institusi.

Menurut Savage-Austin \& Honeycutt (2011), praktek servant leadership secara mendalam akan mempengaruhi organisasi secara alami, diantaranya komunikasi terbuka antar satu dengan yang lain, pertukaran informasi, peningkatan loyalitas antara pimpinan dan anggota organisasi. Keuntungan tambahan dalam mengadopsi filosofi servant leadership termasuk perbaikan dalam proses pengambilan keputusan, peningkatan produktifitas, peningkatan aspek moral dan pengurangan turnover karyawan. Penghambat praktek servant leadership yang lazim ditemukan yakni terkait budaya perusahaan, ketakutan adanya perubahan, kurangnya pengetahuan mengenai filosofi praktek servant leadership.

Tri Bekti Agung Wibowo- Efektifitas Program Servant Leadership Terhadap Kepuasan Karyawan Di Industri Farmasi [Vol 11, No 1 (2020): April 2020] JBTI 


\section{Kepuasan Karyawan}

Menurut Heathfield (2019), kepuasan karyawan adalah istilah yang digunakan untuk menggambarkan apakah karyawan bahagia dan terpenuhi keinginan dan kebutuhan mereka di tempat kerja. Banyak pengujian menyatakan bahwa kepuasan karyawan adalah faktor dalam motivasi karyawan, pencapaian tujuan karyawan, dan moral karyawan yang positif di tempat kerja. Faktor-faktor yang berkontribusi terhadap kepuasan karyawan termasuk memperlakukan karyawan dengan rasa hormat, memberikan pengakuan karyawan secara berkala, memberdayakan karyawan, menawarkan manfaat dan kompensasi di atas rata-rata industri, memberikan tunjangan karyawan dan menyediakan kegiatan di perusahaan. Faktor penting dengan kepuasan karyawan adalah bahwa karyawan yang puas harus melakukan pekerjaan dan memberikan kontribusi yang dibutuhkan perusahaan.

Menurut Lanterman (2013), kepuasan kerja mengacu pada pandangan atau perasaan positif yang dimiliki seseorang tentang pekerjaannya. Ukuran ini dapat digunakan untuk menggambarkan perasaan umum tentang pekerjaan, berbagai aspek pekerjaan, atau pengalaman kerja. Variasi dalam kepuasan kerja dapat mempengaruhi kesehatan, kinerja kerja individu, dan kinerja organisasi. Menurut Situmorang \& Sarjono (2012) motivasi kerja dan kompensasi berkontribusi secara simultan terhadap kepuasan kerja.

\section{METODE PENELITIAN}

Subjek penelitian adalah subjek yang dituju untuk diteliti. Dalam penelitian ini, yang menjadi subjek penelitian adalah karyawan perusahaan yang merupakan bawahan dari para manager peserta program servant leadership. Ada 6 manager (disebut dengen kode A, B, C, D, E dan F) yang diteliti dalam studi ini.

Proses pengumpulan data dilakukan melalui kuesioner, yakni metode pengumpulan data dengan memberikan atau menyebarkan suatu pertanyaan kepada responden. Setiap responden diminta pendapatnya dengan memberikan jawaban dari pertanyaan yang diajukan. Kuesioner didesain berdasarkan skala Likert. Menurut Preedy (2010), skala Likert merupakan suatu jenis skala respons psikometrik di mana responden menentukan tingkat persetujuan mereka terhadap suatu pernyataan, biasanya dalam lima poin: (1) sangat tidak setuju; (2) tidak setuju; (3) setuju dan tidak setuju; (4) setuju; (5) sangat setuju. Pengambilan data dilakukan pada pertengahan tahun 2018, yakni sebagai data awalan (saat program baru berjalan) dan pada pertengahan tahun 2019, saat program sudah berjalan 1 tahun.

Metode yang dilakukan dalam studi ini mengadopsi dari metode yang dilakukan oleh Fecikova (2004), Angelova \& Zekiri (2011) dan Gunawan \& Iqbal (2018). Hasil kuesioner dianalisa menggunakan uji validitas, uji reliabilitas dan paired t-test. Hal ini untuk menguji signifikansi pengaruh program servant leadership training. Kemudian dilanjutkan pada kalkulasi Satisfaction Index (SI) dengan weighted scoring pada 3 dimensi (listening, persuasion, foresight). Hal ini dikarenakan program training yang dilakukan berfokus pada listening, persuasion dan foresight. Hasil SI kemudian dibandingkan antara sebelum dan sesudah training.

\section{HASIL DAN PEMBAHASAN Uji Validitas}

Uji validitas dilakukan dengan menggunakan software SPSS, dengan membandingkan nilai $r$ hitung yang merupakan nilai item dari corrected item-total correlation dengan dari $\mathrm{r}$ tabel pada signifikansi 0,05. Pada kasus ini besarnya df dapat dihitung 53-2 atau df 51 dengan alpha 0,05 didapat $r$ tabel 0,2706 ; jika $r$ hitung lebih besar dari $r$ tabel dan nilai $r$ positif, maka butir pertanyaan tersebut dikatakan valid. 
Tabel 1. Hasil Uji Validitas

\begin{tabular}{|l|l|c|c|c|}
\hline & Dimensi & r hitung & r tabel & Keterangan \\
\hline \multirow{4}{*}{ Sebelum } & Listening & 0,369 & & Valid \\
\cline { 2 - 3 } & Persuasion & 0,345 & & Valid \\
\cline { 2 - 3 } & Foresight & 0,352 & \multirow{3}{*}{0,2706} & Valid \\
\hline \multirow{3}{*}{ Sesudah } & Listening & 0,322 & & Valid \\
\cline { 2 - 3 } & Persuasion & 0,352 & & Valid \\
\cline { 2 - 3 } & Foresight & 0,363 & & Valid \\
\hline
\end{tabular}

Hasil pengujian validitas menunjukkan bahwa semua item yang di uji dinyatakan valid karena nilai corrected item-total correlation lebih besar dari $\mathrm{r}$ tabel ( $\mathrm{r}$ hitung $>\mathrm{r}$ tabel) pada signifikansi $0,05(5 \%)$.

\section{Uji Reliabilitas}

Uji reliabilitas dalam penelitian ini menggunakan koefisien cronbach's alpha $(\alpha)$, Untuk uji reliabilitas, semakin dekat nilai koefisien keandalan dengan 1,0 maka akan semakin baik. Pada umumnya, nilai kurang dari 0,6 dianggap dapat diterima, nilai dalam kisaran 0,7 dianggap baik, dan nilai lebih dari 0,8 dianggap sangat baik. Berikut ini merupakan tabel nilai cronbach's alpha masing-masing hasil uji dari responden.

Tabel 2. Hasil Uji Reliabilitas

\begin{tabular}{|l|l|l|l|c|c|c|c|}
\hline & & \multicolumn{7}{|c|}{ Cronbach's alpha } \\
\cline { 3 - 8 } & & A & B & C & D & E & F \\
\hline \multirow{3}{*}{ Sebelum } & Listening & 0,762 & 0,745 & 0,748 & 0,753 & 0,761 & 0,761 \\
\cline { 2 - 8 } & Persuasion & 0,720 & 0,736 & 0,752 & 0,727 & 0,741 & 0,732 \\
\cline { 2 - 8 } & Foresight & 0,767 & 0,761 & 0,746 & 0,759 & 0,748 & 0,752 \\
\hline \multirow{3}{*}{ Sesudah } & Listening & 0,731 & 0,739 & 0,737 & 0,729 & 0,740 & 0,727 \\
\cline { 2 - 8 } & Persuasion & 0,750 & 0,757 & 0,740 & 0,755 & 0,740 & 0,738 \\
\cline { 2 - 8 } & Foresight & 0,725 & 0,731 & 0,733 & 0,716 & 0,736 & 0,728 \\
\hline
\end{tabular}

Keandalan konsistensi antar item atau koefisien keandalan cronbach's alpha yang terdapat pada tabel diatas semuanya di atas 0,7 atau dapat dikatakan baik.

\section{Paired t-test}

Untuk menyimpulkan apakah terdapat perbedaan antara sebelum dan sesudah program servant leadership maka dilakukan paired t-test dengan tingkat kepercayaan 95\%. Bila hasil uji menunjukkan angka lebih kecil dari 0,05 dapat disimpulkan bahwa ada perbedaan antara sebelum dan sesudah program training atau ada dampak efektifitas program training yang dijalankan.

Tabel 3. Hasil Uji Paired t-test

\begin{tabular}{|l|c|c|c|c|c|c|}
\hline & \multicolumn{6}{|c|}{ Sig (2-tailed) } \\
\cline { 2 - 7 } & $\mathbf{A}$ & $\mathbf{B}$ & $\mathbf{C}$ & $\mathbf{D}$ & $\mathbf{E}$ & $\mathbf{F}$ \\
\hline Listening & $0,442^{*}$ & 0,000 & 0,000 & $0,062^{*}$ & 0,004 & 0,045 \\
\hline Persuasion & $0,598^{*}$ & 0,000 & 0,037 & $0,195^{*}$ & 0,016 & $0,745^{*}$ \\
\hline Foresight & $0,066^{*}$ & 0,000 & 0,000 & 0,000 & 0,000 & 0,000 \\
\hline
\end{tabular}

Tri Bekti Agung Wibowo- Efektifitas Program Servant Leadership Terhadap Kepuasan Karyawan Di Industri Farmasi [Vol 11, No 1 (2020): April 2020] JBTI 
Dari tabel 3, untuk nilai yang lebih besar dari 0,05 diberikan notasi bintang (*). Angka yang lebih besar dari 0,05 berarti tidak ada perbedaan antara sebelum dan sesudah program training atau tidak ada dampak efektifitas program training yang dijalankan.

Karyawan yang merupakan bawahan dari manager A memberikan respon bahwa tidak ada dampak efektifitas program training dari 3 dimensi (listening, persuasion, foresight). Untuk karyawan dari manager D memberikan respon bahwa tidak ada dampak efektifitas program training dari 2 dimensi (listening dan persuasion). Untuk karyawan dari manager $\mathrm{F}$ memberikan respon bahwa tidak ada dampak efektifitas program training dari 1 dimensi (persuasion).

Pengujian dilanjutkan dengan mengadopsi model satisfaction index, dilakukan pengukuran sebelum dan sesudah program training. Menggunakan 3 dimensi yang sama (listening, persuasion, foresight) dengan weighted scoring 35\% untuk listening dan persuasion, serta $30 \%$ untuk foresight. Nilai ini didasarkan pada karakteristik jenis pekerjaan dimana dimensi listening dan persuasion lebih dibutuhkan oleh para manager peserta program servant leadership.

Tabel 4. Hasil Satisfaction Index Sebelum Program Servant Leadership

\begin{tabular}{|c|c|c|c|c|c|c|c|c|}
\hline \multirow[b]{2}{*}{ Subject } & \multicolumn{3}{|c|}{ Dimension } & \multicolumn{3}{|c|}{ Weighted Scoring } & \multirow[b]{2}{*}{$\begin{array}{c}\text { Weighted } \\
\text { Total }\end{array}$} & \multirow[b]{2}{*}{ SI } \\
\hline & $\begin{array}{l}\text { Listening } \\
\text { (i) }\end{array}$ & $\begin{array}{l}\text { Persuasion } \\
\text { (ii) }\end{array}$ & $\begin{array}{l}\text { Foresight } \\
\text { (iii) }\end{array}$ & $\begin{array}{c}\text { (i) } \\
35 \%\end{array}$ & $\begin{array}{l}\text { (ii) } \\
35 \%\end{array}$ & $\begin{array}{l}\text { (iii) } \\
30 \%\end{array}$ & & \\
\hline $\mathbf{A}$ & 3,4 & 3,4 & 3,5 & 1,2 & 1,2 & 1,0 & 3,4 & $69 \%$ \\
\hline B & 2,1 & 2,5 & 2,0 & 0,7 & 0,9 & 0,6 & 2,2 & $44 \%$ \\
\hline $\mathbf{C}$ & 3,1 & 3,2 & 2,7 & 1,1 & 1,1 & 0,8 & 3,0 & $61 \%$ \\
\hline D & 2,6 & 2,9 & 2,1 & 0,9 & 1,0 & 0,6 & 2,6 & $51 \%$ \\
\hline $\mathbf{E}$ & 3,3 & 3,2 & 2,7 & 1,1 & 1,1 & 0,8 & 3,1 & $62 \%$ \\
\hline $\mathbf{F}$ & 2,9 & 3,4 & 2,6 & 1,0 & 1,2 & 0,8 & 3,0 & $60 \%$ \\
\hline
\end{tabular}

Tabel 5. Hasil Satisfaction Index Sesudah Program Servant Leadership

\begin{tabular}{|c|c|c|c|c|c|c|c|c|}
\hline \multirow[b]{2}{*}{ Subject } & \multicolumn{3}{|c|}{ Dimension } & \multicolumn{3}{|c|}{ Weighted Scoring } & \multirow[b]{2}{*}{$\begin{array}{c}\text { Weighted } \\
\text { Total }\end{array}$} & \multirow[b]{2}{*}{ SI } \\
\hline & $\begin{array}{l}\text { Listening } \\
\text { (i) }\end{array}$ & $\begin{array}{l}\text { Persuasion } \\
\text { (ii) }\end{array}$ & $\begin{array}{l}\text { Foresight } \\
\text { (iii) }\end{array}$ & $\begin{array}{c}\text { (i) } \\
35 \%\end{array}$ & $\begin{array}{l}\text { (ii) } \\
35 \%\end{array}$ & $\begin{array}{l}\text { (iii) } \\
30 \%\end{array}$ & & \\
\hline $\mathbf{A}$ & 3,6 & 3,3 & 3,1 & 1,3 & 1,2 & 0,9 & 3,3 & $67 \%$ \\
\hline B & 2,9 & 3,3 & 3,1 & 1,0 & 1,2 & 0,9 & 3,1 & $62 \%$ \\
\hline $\mathrm{C}$ & 4 & 3,9 & 3,9 & 1,4 & 1,4 & 1,2 & 3,9 & $79 \%$ \\
\hline D & 3,1 & 3,3 & 3,2 & 1,1 & 1,2 & 1,0 & 3,2 & $64 \%$ \\
\hline $\mathbf{E}$ & 3,9 & 3,9 & 3,9 & 1,4 & 1,4 & 1,2 & 3,9 & $78 \%$ \\
\hline $\mathbf{F}$ & 3,5 & 3,5 & 3,5 & 1,2 & 1,2 & 1,1 & 3,5 & $70 \%$ \\
\hline
\end{tabular}

Tabel 6. Perbandingan Satisfaction Index Sebelum dan Sesudah Program

\begin{tabular}{|c|c|c|c|}
\hline \multirow{2}{*}{ Subjek } & \multicolumn{2}{|c|}{ Satisfaction Index } & \multirow{2}{*}{ (ii) - (i) } \\
\cline { 2 - 4 } & Sebelum (i) & Sesudah (ii) & $-2 \%$ \\
\hline A & $69 \%$ & $67 \%$ & $18 \%$ \\
\hline B & $44 \%$ & $62 \%$ & $18 \%$ \\
\hline C & $61 \%$ & $79 \%$ & $13 \%$ \\
\hline D & $51 \%$ & $64 \%$ & $16 \%$ \\
\hline E & $62 \%$ & $78 \%$ & $10 \%$ \\
\hline \multicolumn{3}{|c|}{ Rata-rata } \\
\hline
\end{tabular}

Tri Bekti Agung Wibowo- Efektifitas Program Servant Leadership Terhadap Kepuasan Karyawan Di Industri Farmasi [Vol 11, No 1 (2020): April 2020] JBTI 
Dari tabel 6, terlihat adanya korelasi antara pengujian dengan mengadopsi satisfaction index dan dengan paired t-test. Karyawan dari manager A menunjukkan satisfaction index yang bernilai negatif. Hal ini berarti tidak ada dampak dari program servant leadership yang dilakukan terhadap kepuasan karyawan. Kemudian untuk karyawan dari manager D dan F juga menunjukkan nilai peningkatan satisfaction index yang relatif lebih rendah daripada manager $\mathrm{B}, \mathrm{C}$ dan $\mathrm{E}$. Hal ini seperti yang telah dinyatakan oleh Ragnarsson et al (2018), bahwa para pemimpin mengalami kesulitan dan tantangan dalam mempraktekkan servant leadership. Chandaruba (2018) juga menyatakan bahwa ada banyak tantangan dalam menerapkan servant leadership. Pada dasarnya gaya kepemimpinan ini didasarkan pada kepercayaan, hubungan dan rasa kepemilikan dalam pekerjaan. Hal ini tidak dapat terjadi dalam waktu yang pendek. Pada beberapa kasus, servant leader membutuhkan waktu lebih untuk dapat lebih erat dengan karyawannya, memahami dan memotivasi mereka.

Secara keseluruhan, dari 6 manager yang mengikuti program servant leadership, sebagian besar menunjukkan perbedaan antara sebelum dan sesudah program training, dengan kata lain secara umum terdapat dampak efektifitas program training yang dijalankan terhadap kepuasan karyawan di industri farmasi. Hal ini sejalan dengan studi yang dilakukan oleh Alafeshat \& Aboud (2019) di sektor industri penerbangan, dimana terdapat korelasi positif antara servant leadership dengan kepuasan karyawan.

\section{KESIMPULAN DAN SARAN}

Dari hasil analisis data dan pembahasan yang dilakukan dalam studi ini, dapat ditarik kesimpulan bahwa terdapat dampak efektifitas program servant leadership terhadap kepuasan karyawan di industri farmasi. Pada beberapa kasus, servant leader membutuhkan waktu lebih untuk dapat lebih erat dengan karyawannya, memahami dan memotivasi mereka. Dari hasil pembahasan yang sudah diuraikan sebelumnya, maka saran bagi peneliti selanjutnya yakni diharapkan dapat memperbaiki keterbatasan yang ada dalam penelitian, tahun pengamatan yang lebih panjang untuk mendapatkan hasil yang lebih komprehensif. Selain itu, bagi perusahaan diharapkan dapat memberikan perhatian dan waktu lebih, apabila manager yang sedang berusaha menerapkan servant leadership belum memperlihatkan hasil yang diharapkan dalam waktu cepat.

\section{DAFTAR PUSTAKA}

Alafeshat, R., \& Aboud, F. (2019). Servant Leadership Impact on Organizational Performance: The Mediating Role of Employee Engagement. International Journal of Human Resources Studies, 9(3), 85-100.

Angelova, B., \& Zekiri, J. (2011). Measuring Customer Satisfaction with Service Quality Using American Customer Satisfaction Model (ACSI Model). International Journal of Academic Research in Business and Social Sciences, 1(3), 236-258.

Arain, G., Hameed, I., \& Crawshaw, J. (2019). Servant Leadership and Follower Voice: The Roles of Follower Felt Responsibility for Constructive Change and Avoidance-Approach Motivation. European Journal of Work and Organizational Psychology, 28(4), 555-565.

Azizah, N., \& Livikacansera, S. (2016). Mengenal Generasi Millenial, Kementrian Komunikasi dan Informatika. Retrieved February 26, 2020, from https://www.kominfo.go.id/content/detail/8566/mengenal-generasi-millennial

Bao, Y., Li, C., \& Zhao, H. (2018). Servant Leadership and Engagement: A Dual Mediation Model. Journal of Managerial Psychology, 33(6), 406-417.

Barbuto Jr, J., \& Gottfredson, R. (2016). Human Capital, The Millennial's Reign, and The Need for Servant Leadership. Journal of Leadership Studies, 10(2), 59-63.

Tri Bekti Agung Wibowo- Efektifitas Program Servant Leadership Terhadap Kepuasan Karyawan Di Industri Farmasi [Vol 11, No 1 (2020): April 2020] JBTI 
Brewer, C. (2010). Servant Leadership: A Review of Literature. Online Journal of Workforce Education and Development, 4(2), 3.

Chandaruba, S. (2019). The Prospects and Challenges of Adopting Servant-Leadership Philosophy in a Tanzania Public Leadership Context. Journal of Public Administration and Governance, 9(1), 168-190.

Charles, D. (2015). Effects of Servant Leadership on Satisfaction with Leaders: Inclusion of Situational Variables. Emerging Leadership Journeys, 8(1), 46-61.

Corinna, A., \& Cahyono, E. (2019). Pola Perilaku Konsumsi Generasi Millenial Terhadap Produk Fashion Perspektif Monzer Kahf: Studi Kasus Mahasiswi Universitas Airlangga. Jurnal Ekonomi Syariah Teori dan Terapan, 6(2), 319-330.

Eva, N., Robin, M., Sendjaya, S., van Dierendonck, D., \& Liden, R. C. (2019). Servant Leadership: A Systematic Review and Call for Future Research. The Leadership Quarterly, 30(1), 111132.

Farrington, S., \& Lillah, R. (2019). Servant Leadership and Job Satisfaction Within Private Healthcare Practices. Leadership in Health Services, 32(1), 148-168.

Fecikova, I. (2004). An Index Method for Measurement of Customer Satisfaction. The TQM Magazine, 16(1), 57-66.

Gong, B., Greenwood, R., Hoyte, D., Ramkissoon, A., \& He, X. (2018). Millennials and Organizational Citizenship Behavior: The Role of Job Crafting and Career Anchor on Service. Management Research Review, 41(7), 774-788.

Gunawan, A., \& Iqbal. (2018). Quality Measurement Customer Satisfaction Index (CSI) Method and Importance-Performing Analysis (IPA) Diagram PT. ASDP Indonesia Ferry (Persero) Merak Banten. Journal of Engineering and Management in Industrial System, 6(1), 11-19.

Heathfield, S. (2019). How to Foster Employee Satisfaction. Retrieved February 20, 2020, from https://www.thebalancecareers.com/employee-satisfaction-1918014

Lanterman, J. (2013). Officers' Job Satisfaction. In K. Peak (Ed.), Encyclopedia of Community Policing and Problem Solving. Thousand Oaks: SAGE Publications, Ltd.

Leslie, J., \& Palmisano, K. (2014). The Leadership Challenge in the Pharmaceutical Sector What Critical Capabilities are Missing in Leadership Talent and How Can They be Developed? Retrieved February 20, 2020, from Center for Creative Leadership: https://www.ccl.org/wpcontent/uploads/2016/09/leadership-challenge-pharmaceutical-center-for-creativeleadership.pdf

Liden, R., Wayne, S., Liao, C., \& Meuser, J. (2014). Servant Leadership and Serving Culture: Influence on Individual and Unit Performance. Academy of Management Journal, 57(5), 1434-1452.

Long, S. (2017). Exploring Which Leadership Styles are Effective with Millennial Employees. Walden Dissertations and Doctoral Studies Collection.

Mc Cann, J., Graves, D., \& Cox, L. (2014). Servant Leadership, Employee Satisfaction an Organizational Performance in Rural Community Hospitals. International Journal of Business and Management, 9(10), 28.

Melchar, D., \& Bosco, S. (2010). Achieving High Organization Performance through Servant Leadership. The Journal of Business Inquiry, 9(1), 74-88.

Nawalkha, A. (2018). The Rise of The Millennial, And Why They're Changing Work for The Better. Retrieved February 26, 2020, from Forbes Coaches Council: https://www.forbes.com/sites/forbescoachescouncil/2018/11/08/the-rise-of-the-millennialand-why-theyre-changing-work-for-the-better/\#1 aee26125e12

Preedy, V. (2010). 5-Point Likert Scale. In W. R.R (Ed.), Handbook of Disease Burdens and Quality of Life Measures. New York: Springer.

Tri Bekti Agung Wibowo- Efektifitas Program Servant Leadership Terhadap Kepuasan Karyawan Di Industri Farmasi [Vol 11, No 1 (2020): April 2020] JBTI 
Ragnarsson, S., Krisjansdottir, E., \& Gunnarsdottir, S. (2018). To Be Accountable While Showing Care: The Lived Experience of People in a Servant Leadership Organization. SAGE Open, 1(12), 1-12.

Sakeru, A., Hermawan, A., \& Triyonggo, Y. (2019). Pengaruh Employee Engagement, Pemberdayaan, dan Komitmen Organisasi Terhadap Kinerja Karyawan PT. Toyota Motormanufacturing Indonesia. Jurnal Manajemen Teori dan Terapan, 12(2), 126-148.

Savage-Austin, A., \& Honeycutt, A. (2011). Servant Leadership: A Phenomenological Study of Practices, Experiences, Organizational Effectiveness, and Barriers. Journal of Business \& Economic Research, 9(1), 126-148.

Situmorang, S., \& Sarjono, H. (2012). The Influence of Work's Motivation and Compensation Effect Towards Employee Satisfaction, and The Impact on The Work Performance at State Employees Civil Sub Company, Kebun Jeruk, West Jakarta. Jurnal Manajemen Teori dan Terapan, 1(1), 45-55. 